\title{
KELEMBAGAAN PUSAT KEGIATAN BELAJAR MASYARAKAT SEBAGAI AGEN PENGEMBANGAN MASYARAKAT
}

\begin{abstract}
Entoh Tohani*
Abstract

The research was conducted to evaluate the performance of Community Learning Activities Center (CLAC) as an educational institution in empowering community. The research which is an evaluative study using the Stakes's evaluation model, took place at CLACs in Bantul, Yogyakarta Province. The findings show, firstly, each function of the CLACs has been put into practices. However, the implementation is not done effectively based on the criteria. It indicates that the performance is not organized professionally. Secondly, the CLACs have been able to produce meaningful learning outcomes such as creating positive behavior changes of targeted individuals or communities. However, the CLACs do not assign a greater impact on broader and multidimensional context of community empowerment.. Thirdly, there are threats that give negative influences on the implementation of the CLACs in terms of structural, interactional, and cultural aspects resulted from both internal and external environment of the CLAC institution. Therefore, bases on the findings, in the future the development of the CLACs should be planned and oriented to create the community toward more developed and comprehensive aspects of lives accompanied with the continuous development of strong commitment from stakeholders.
\end{abstract}

Keywords: evaluation, CLAC, nonformal education, community development

\begin{abstract}
Abstrak
Keberhasilan PKBM dalam mengembangkan masyarakat ditentukan oleh pelaksanaan kinerja fungsifungsi kelembagaannya. Pemahaman objektif terhadap kinerja diperlukan untuk mengembangkan PKBM. Penelitian ini merupakan penelitian evaluatif dengan subyek penelitian yaitu 12 PKBM di Kab. Bantul, DIY yang dipilih secara bertujuan. Pengumpulan data dilakukan dengan metode wawancara, dokumentasi, dan observasi. Analisis data dilakukan dengan teknik analisis data model interaktif, keabsahan data dilakukan dengan triangulasi, diskusi ahli, dan perpanjangan pengamatan. Hasil penelitian menunjukkan bahwa pertama, ditinjau dari pemikiran evaluatif mengenai aspek: anteseden, proses dan outcome, pelaksanaan fungsi-fungsi kelembagaan PKBM belum optimal terlaksana; kedua, PKBM mampu membentuk perubahan perilaku positif individu dan/atau masyarakat, walau PKBM belum optimal memberikan dampak (outcome) besar terhadap masyarakat; ketiga, terdapat berbagai kendala penyelenggaraan PKBM baik dalam aspek struktural, interaksional, dan kultural yang berasal dari internal maupun eksternal lembaga. Oleh karena itu, pengembangan PKBM perlu dilakukan terencana dan diorientasikan untuk menciptakan masyarakat maju pada seluruh aspek kehidupannya, disertai pengembangan komitmen bersama yang berkelanjutan.

Kata-kata kunci: Evaluasi, PKBM, PNF,Pengembangan masyarakat
\end{abstract}

Kata-kata kunci: evaluasi, PKBM, pendidikan nonformal, pengembangan masyarakat

\section{PENDAHULUAN}

Bentuk penyelenggaraan pendidikan yang mengutamakan keikutsertaan masyarakat dan dilandasi pemikiran bahwa masyarakat sebagai subjek dalam pengembangan pendidikan salah satunya adalah

* Dosen Jurusan PLS FIP UNY
Pusat Kegiatan Belajar Masyarakat (PKBM) atau community learning center (CLC). PKBM dimaknai sebagai suatu tempat belajar lokal (setempat) di luar sistem pendidikan formal, baik berada di pedesaan maupun di tempat-tempat lain. PKBM biasanya dibangun dan dikelola oleh masyarakat setempat untuk 
membuka kesempatan belajar bagi masyarakat dan peningkatan kualitas hidup (Unesco, 2008). Lahirnya lembaga PKBM didasari oleh gagasan bahwa peningkatan kualitas kehidupan masyarakat baik individu maupun kelompok dapat dilakukan sendiri oleh masyarakat dengan mengandalkan kemampuan untuk mengelola berbagai potensi yang dimiliki masyarakat secara mandiri, kreatif, dan bermanfaat.

PKBM diharapkan menjadi lembaga yang mampu memberikan layanan kepada masyarakat untuk mengakses berbagai peluang yang ada di luar lingkungannya guna memenuhi kebutuhan hidupnya. Peluang yang terdapat di masyarakat sangat beragam baik bersifat memberikan keuntungan ekonomi, mengembangkan kemampuan berusaha, mengembangkan kegiatan yang bersifat kesenangan maupun peluang guna memperoleh pengembangan usaha dan peningkatan produk atau jasa yang dihasilkan. Dalam hal ini, PKBM sebagai lembaga yang bergerak dalam pembangunan pendidikan memiliki fungsi strategis yaitu berperan sebagai jembatan atau perantara antara kepentingan individu atau kelompok sasaran dengan masyarakat yang membutuhkan jasa atau produk dari PKBM.

Dalam perkembangannya, banyak PKBM yang belum optimal menyelenggarakan berbagai kegiatan pendidikan disebabkan beragam permasalahan yang dihadapi PKBM baik pada aspek pengelolaan, mutu sumber daya manusia, ketersediaan fasilitas, dan lingkungan masyarakat di mana PKBM berada. Pada aspek pengelolaan kelembagaan PKBM nampak diselenggarakan kurang bervariasi, artinya program pendidikan yang dilaksanaan PKBM cenderung tidak memiliki terobosan-terobosan baru yang memungkinkan program-program inovatif terwujud. Begitu pula dari segi kuantitas, program yang dilaksanakan merupakan program rutin PKBM sebagaimana program-program yang dilaksanakan sebelumnya, misalnya hanya menyelenggarakan program keaksaraan fungsional, kesetaraan, dan program kecakapan hidup (life skills).

Dalam rangka mewujudkan masyarakat gemar belajar (learning society), permasalahan-permasalahan yang dihadapi PKBM harus dapat dipecahkan seoptimal mungkin. Layanan pendidikan kepada masyarakat harus menjamin ketersediaan akses, pengelolaan yang dilakukan secara efektif dan efesien, peningkatan mutu penyelenggaraan PKBM, dan akuntabilitas yang baik. Selain itu, PKBM dituntut mampu menghadapi berbagai tantangan internal dan eksternal sebagai konsekuensi dari perubahan-perubahan yang terjadi baik di lingkungan PKBM maupun sosial masyarakat. Tantangan internal mencakup peningkatan kualitas kemampuan sumber daya manusia, peningkatan proses pembelajaran, dan meningkatkan kemandirian dalam pendanaan. Sedangkan tantangan eksternal meliputi peningkatkan kemampuan belajar warga masyarakat melalui penawaran program-program pendidikan nonformal yang bermutu dan pembentukan kelompok-kelompok belajar.

Peningkatan mutu penyelenggaraan kelembagaan PKBM dipandang perlu untuk dilakukan terus-menerus. Terwujudnya PKBM yang berkualitas, dalam jangka panjang akan menjamin upaya pemberdayaan masyarakat baik individu, kelompok, maupun organisasi. PKBM diharapkan dapat membentuk warga masyarakat yang berkemampuan mengembangkan diri dan lingkungannya, mengoptimalkan potensi yang ada secara terencana, terarah dan terintegrasi, dan mampu membelajarkan masyarakatnya guna tercapai kesejahteraan diri dan masyarakatnya (Ife, 1997; Korten, 1986).

Salah satu penentu keberhasilan pencapaian tujuan PKBM yaitu terwujudnya masyarakat yang berdaya dalam bidang sosial, politik, dan budaya sangat tergantung pada kompetensi profesional PKBM dan personalianya dalam menciptakan sistem pengelolaan yang efektif, transparan dan bertanggung jawab. Hal ini akan tercermin dari pelaksanaan fungsi-fungsi yang efektif dan efisien seperti memiliki pemahaman objektif dan komprehensif terhadap masyarakat dan kebutuhankebutuhannya, berjalannya kegiatan-kegiatan PKBM secara terencana dan terorganisasi, pengelolaan sumber daya yang efektif dan efisien, tercipta iklim kerja sama dan jaringan yang kondusif, proses monitoring dan evaluasi yang berkelanjutan dan transparan, ketatalaksanaan dokumentasi dan diseminasi yang meningkatkan partisipasi, dan terencananya pengembangan kapasitas personalia yang berkelanjutan (Unesco, 2008). Selain itu, personalia yang dimiliki PKBM perlu membangun kesadaran dan menginternalisasi nilai-nilai positif yang menjadi arahan dalam memberikan pelayanan pendidikan kepada warga masyarakat.

Terselenggaranya fungsi-fungsi kelembagaan PKBM di atas diharapkan mampu mewujudkan PKBM sebagai lembaga pendidikan berbasis masyarakat atau community based education (Galbraith, 1995) yang dapat menjadi penyedia layanan pendidikan yang selalu menyediakan kesempatan pendidikan dan pelatihan, menjadi sumber informasi, serta menjadi sarana kegiatan pengembangan masyarakat yang belum dan mampu mengembangkan jaringan sosial (Zaenudin, 2003). Disadari, pelaksanaan fungsi kelembagaan PKBM tidak mudah dan pada kenyataan sering 
menghadapi berbagai kendala baik pada sumber daya manusia yang dimiliki, fasilitas yang digunakan, lingkungan, dan/atau peran serta masyarakat. Kendalakendala ini dapat berakibat pada kekurangoptimalan pemberian layanan pendidikan yang akhirnya kualitas hasil pembelajaran kelompok sasaran maupun masyarakat tidak tercapai.

Berdasarkan pada pemikiran di atas, dalam konteks memajukan masyarakat dan dimensinya, upaya pengembangan PKBM perlu dilakukan guna terjaminnya keberlanjutan PKBM dengan terlebih dahulu memahami berbagai aspek kegiatan yang dilakukan oleh PKBM. Dengan demikian diperoleh suatu pemahaman yang mendalam dan objektif mengenai ketercapaian berbagai fungsi kelembagaan PKBM yang dapat menjadi suatu bahan masukan guna menghasilkan langkah-langkah perbaikan bagi terwujudnya PKBM yang mampu memberikan kesempatan pembelajaran yang lebih terbuka, menjadi meningkatkan kualitas hasil pelayanan program pendidikan, menyelenggarakan proses pembelajaran yang lebih inovatif dan kreatif, dan pengelolaan kelembagaan yang akuntabilitas, partisipasi, dan memperoleh kepercayaan pihak-pihak terkait.

\section{METODOLOGI PENELITIAN}

Penelitian ini merupakan penelitian evaluatif dengan menggunakan model penelitian evaluatif dari Stake (Stufflebeam and Shinkfield, 1984) guna mengkaji fungsi-fungsi kelembagaan PKBM yang menjadi fokus penelitian. Subjek penelitian ini adalah PKBM-PKBM di wilayah Kabupaten Bantul, Provinsi DIY yang dipilih dengan teknik pengambilan sampel bertujuan (purposive sampling). PKBM yang dijadikan subjek penelitian berjumlah 12 lembaga yang mewakili empat karakteristik wilayah. Pengumpulan data dilakukan dengan menggunakan metode wawancara, dokumentasi, observasi, dan kuesioner. Selanjutnya, data yang diperoleh dianalisis dengan menggunakan analisis data model interaktif (Miles \& Huberman, 2007). Guna diperoleh keabsahan data dilakukan triangulasi, diskusi dengan ahli, dan perpanjangan pengamatan.

\section{HASIL PENELITIAN}

Pusat Kegiatan Belajar Masyarakat (PKBM) sebagai lembaga pendidikan perlu diketahui keberhasilannya dalam mencapai tujuan. Untuk ini, diperlukan suatu penilaian terhadap kinerja kelembagaan PKBM yang bermanfaat untuk menjadi umpan balik guna melakukan perbaikan-perbaikan dalam menyelenggarakan PKBM pada masa mendatang. Mengacu pada pemikiran di atas, penelitian ini dilakukan untuk mengkaji fungsi kelembagaan PKBM yang mencakup: identifikasi kebutuhan, perencanaan program dan kegiatan, mobilisasi dan pemanfaatan sumber daya, jaringan kemitraan, monitoring, evaluasi, dokumentasi, diseminasi, dan pengembangan kapasitas personalia. Fungsi-fungsi PKBM tersebut dalam pengkajian tidak dapat dipandang terpisah, namun saling memiliki keterkaitan. Berikut hasil penelitian yang menjelaskan kinerja fungsi-fungsi kelembagaan PKBM yang dikaji mendasarkan pada pemikiran evaluatif.

Pertama, proses identifikasi kebutuhan. Pengidentifikasian kebutuhan pendidikan yang dilakukan PKBM disajikan dalam tabel berikut. Berdasarkan tabel dimaksud, pada semua PKBM yang diteliti, kelompok sasaran program pendidikan adalah mereka yang dipandang kurang beruntung (marginal) dalam berbagai bidang khususnya dalam bidang pendidikan. Misalnya seperti yang belum bekerja dan belum dapat melanjutkan pendidikan ke jenjang formal dan buta huruf. Sebaliknya, warga masyarakat yang tergolong beruntung belum dapat dilayani oleh PKBM. Di samping itu, penentuan kebutuhan pendidikan juga dilakukan dengan cara menyesuaikan dengan kebijakan-kebijakan mengenai program yang digalakkan oleh pemerintah. Namun, dalam pengidentifikasian kebutuhan dipahami bahwa keberagamaan dan pemetaan kebutuhan masih belum terselenggara.

Tabel 1. Identifikasi Kebutuhan

\begin{tabular}{|c|c|c|c|}
\hline & Kenyataan & Standar & Judgment \\
\hline 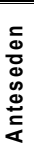 & $\begin{array}{l}\text { - Kondisi riil masyarakat } \\
\text { - Fokus pada data kelompok } \\
\text { sasaran dari pemdes, kader, } \\
\text { tokoh masy, kepala sekolah } \\
\text { - Kebijakan pemerintah }\end{array}$ & $\begin{array}{l}\text { - Berbasis pada } \\
\text { masyarakat } \\
\text { - Data potensi dan } \\
\text { sasaran valid, } \\
\text { komprehensif }\end{array}$ & \multirow{3}{*}{$\begin{array}{l}\text { - Identifikasi } \\
\text { kebutuhan } \\
\text { difokuskan pada } \\
\text { kesesuaian } \\
\text { kebutuhan } \\
\text { masyarakat dan } \\
\text { program } \\
\text { pemerintah. } \\
\text { - Partisipasi } \\
\text { kelompok sasarar } \\
\text { masih minim dan } \\
\text { prosedur ilmiah } \\
\text { belum banyak } \\
\text { dilakukan } \\
\text { - Tidak ada } \\
\text { pemetaan } \\
\text { kebutuhan }\end{array}$} \\
\hline $\begin{array}{l}\infty \\
\vdots \\
\infty \\
\vdots \\
\vdots\end{array}$ & $\begin{array}{l}\text { - Penentuan kebutuhan } \\
\text { dilakukan secara bersama oleh } \\
\text { pengelola } \\
\text { - Diskusi dan koordinasi rutin } \\
\text { dalam pertemuan-pertemuan } \\
\text { - Pertimbangan pihak lain } \\
\text { (petugas dikmas, dan tokoh) }\end{array}$ & $\begin{array}{l}\text { - Partisipatif } \\
\text { - Metode pengkajian } \\
\text { beragam } \\
\text { - Fokus pada kajian } \\
\text { ilmiah, dan holistik }\end{array}$ & \\
\hline 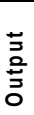 & $\begin{array}{l}\text { - Kebutuhan pendidikan yang } \\
\text { diprioritaskan }\end{array}$ & $\begin{array}{l}\text { - Objektif } \\
\text { - Keberagaman } \\
\text { - Pemetaan prioritas } \\
\text { kebutuhan }\end{array}$ & \\
\hline
\end{tabular}


Kedua, perencanaan program dan kegiatan. Semua PKBM yang diteliti melakukan proses perencanaan secara sederhana/rutinitas dan/atau terkadang perencanaan program menunggu kejelasan informasi tentang hibah. Perencanaan program pendidikan yang kurang sistemik juga ditemui pada PKBM yang diteliti. Rencana-rencana program sebagai hasil proses perencanaan, belum menunjukkan rencana yang menggambarkan perencanaan jangka menengah dilakukan PKBM dideskripsikan dalam Tabel 2.

Tabel 2 Perencanaan Program dan Kegiatan

\begin{tabular}{|c|c|c|c|}
\hline & Kenyataan & Ideal & Judgment \\
\hline 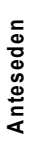 & $\begin{array}{l}\text { - Program disesuaikan } \\
\text { kebutuhan dan protensi } \\
\text { masyarakat, } \\
\text { - Kebijakan/program } \\
\text { pemerintah }\end{array}$ & $\begin{array}{l}\text { - Orientasi kebutuhan } \\
\text { - Berbasis masyarakat }\end{array}$ & \multirow{3}{*}{$\begin{array}{l}\text { - Penyusunan program } \\
\text { sesuai dengan } \\
\text { kebutuhan } \\
\text { pendidikan yang } \\
\text { penting bagi } \\
\text { masyarakat, } \\
\text { - Dominan } \\
\text { penyelenggara } \\
\text { dan/atau pengelola } \\
\text { dan atas } \\
\text { kesepakatan } \\
\text { bersama } \\
\text { - Rencana program } \\
\text { yang kompetitif minim }\end{array}$} \\
\hline $\begin{array}{l}\text { @ } \\
\text { D } \\
\vdots \\
\vdots\end{array}$ & $\begin{array}{l}\text { - Dilakukan secara bersama } \\
\text { oleh pengelola } \\
\text { - Mengacu pada pedoman } \\
\text { tertentu } \\
\text { - Pertimbangan pihak lain } \\
\text { - Koordinasi rutin; } \\
\text { komunikasi informal }\end{array}$ & $\begin{array}{l}\text { - Orientasi pada } \\
\text { waktu tertentu } \\
\text { - Mengacu pada } \\
\text { kajian ilmiah } \\
\text { - Integratif } \\
\text { - Partisipatif } \\
\text { - Kreatif dan inovatif }\end{array}$ & \\
\hline 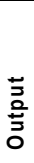 & $\begin{array}{l}\text { - Usulan masih cenderung } \\
\text { ditujukan ke dinas } \\
\text { pendidikan } \\
\text { - Minim ke dinas/pihak lain } \\
\text { - Persetujuan usulan sering } \\
\text { tidak sesuai harapan }\end{array}$ & $\begin{array}{l}\text { - Ragam program } \\
\text { - Berdaya jual } \\
\text { - Kontinuitas } \\
\text { - Berbagai pihak } \\
\text { mendukung }\end{array}$ & \\
\hline
\end{tabular}

Berdasarkan pada tabel di atas, pada aspek keluaran (outcome) perencanaan program pendidikan masih perlu upaya peningkatan. Apabila dilihat dari tingkat daya jualnya, program pendidikan yang ditawarkan masih kurang menunjukkan adanya permintaan dari kelompok pengguna layanan pendidikan. Kondisi ini nampak dengan kerja kerasnya pengelola, tutor, dan penyelenggara untuk mencari langsung, menawarkan, dan memotivasi calon sasaran program untuk berpartisipasi dalam proses pembelajaran. Idealnya, PKBM memiliki program pendidikan yang menarik dan dibutuhkan calon pengguna layanan pendidikan sehingga secara sadar dan aktif mengakses program pendidikan pada PKBM.

Ketiga, mobilisasi dan pemanfaatan sumber daya (material dan manusia). Pelaksanaan berbagai kegiatan PKBM tidak secara mudah dapat terjadi tanpa ketersediaan dan pemanfaatan sumber daya yang memadai baik secara kuantitatif maupun kualitatif. Kegiatan memobilitasi dan memanfaatkan sumber daya material dapat dideskripsikan dalam tabel 3, yang mana nampak jelas bahwa PKBM masih membutuhkan peningkatan kinerja dalam pemanfaatan dan pengelolaan fasilitas yang dimiliki. Dalam pengembangan PKBM jangka panjang, kepemilikan fasilitas secara mandiri salah satu yang perlu menjadi bahan pengambilan keputusan dalam pengembangan berbagai kegiatan PKBM. Kemandirian dalam kepemilikan fasilitas dan pemanfaatannya akan memudahkan PKBM bergerak bebas mencapai tujuannya. Selain itu, fasilitas milik mandiri menjadi bahan pertimbangan guna kepentingan melembagakan PKBM dalam pembangunan pendidikan.

Tabel 3. Pengelolaan Sumber Daya Material

\begin{tabular}{|c|c|c|c|}
\hline & Kenyataan & Standar & Judgment \\
\hline 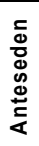 & $\begin{array}{l}\text { - Program pendidikan } \\
\text { - Potensi yang ada } \\
\text { - Dukungan/program pihak lain }\end{array}$ & $\begin{array}{lr}\text { - Akses } & \text { terhadap } \\
\text { sumber } & \text { yang } \\
\text { mudah } & \end{array}$ & \multirow{3}{*}{$\begin{array}{l}\text { - Menekankan } \\
\text { pada } \\
\text { kemudahan } \\
\text { akses dan } \\
\text { keterlaksanaan } \\
\text { program } \\
\text { - Semua PKBM } \\
\text { belum memiliki } \\
\text { fasilitas gedung } \\
\text { mandiri } \\
\text { - Pemanfaatan } \\
\text { dan penataan } \\
\text { masih perlu } \\
\text { dioptimalkan } \\
\text { pada fasisilitas } \\
\text { non-keuangan }\end{array}$} \\
\hline 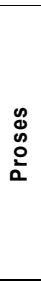 & $\begin{array}{l}\text { - Cara mendapatkan: } \\
\text { peminjaman dari warga, } \\
\text { pemdes atau dinas pendidikan } \\
\text { dengan pendekatan informal; } \\
\text { - Hibah melalui sistem seleksi } \\
\text { - Ketersediaan dan penataan } \\
\text { belum optimal } \\
\text { - Kelengkapan administrasi } \\
\text { fasilitas non keuangan belum } \\
\text { tersedia } \\
\end{array}$ & $\begin{array}{l}\text { - Kemudahan } \\
\text { mendapatkan } \\
\text { - Kelengkapan } \\
\text { - Kondisi } \\
\text { penataan } \\
\text { - Pemanfaatan } \\
\text { - Pengembangan }\end{array}$ & \\
\hline 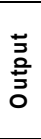 & $\begin{array}{l}\text { - Kegiatan pembelajaran dan } \\
\text { administrasi dapat berjalan, } \\
\text { walau pemanfaatan lebih pada } \\
\text { kegiatan rutin proses } \\
\text { pembelajaran }\end{array}$ & $\begin{array}{l}\text { - Efektivitas dan } \\
\text { efesien } \\
\text { pembelajaran } \\
\text { dan pengelolaan }\end{array}$ & \\
\hline
\end{tabular}

Sedangkan pengelolaan sumber daya manusia dideskripsikan dalam tabel 4. Sumber daya manusia atau personalia yang dimiliki PKBM terdiri dari penyelenggara dan pengelola. Penyelenggara umumnya bertindak sebagai pencetus gagasan awal pendirian lembaga, sedangkan pengelola PKBM terdiri dari ketua pengelola, sekretaris, dan bendahara yang direkrut langsung oleh penyelenggara. Dalam aspek pengelolaan sumber daya manusia, diketahui bahwa personalia yang berada pada semua PKBM yang diteliti direkrut langsung dengan lebih menekankan pada keberadaan fungsi pembelajaran semata. Fungsi-fungsi kelembagaan PKBM belum dilaksanakan oleh individuindividu yang profesional, mampu bekerja secara mandiri, serta memiliki banyak inisiatif dan cara kreatif dalam menjalankan tugasnya.

Tabel 4. Pengelolaan personalia

\begin{tabular}{|c|c|c|c|}
\hline & Kenyataan & Standar & Judgment \\
\hline 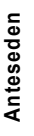 & $\begin{array}{l}\text { - Program pendidikan } \\
\text { - Identifikasi potensi sumberdaya } \\
\text { manusia di masyarakat }\end{array}$ & $\begin{array}{l}\text { - Aksesibilitas } \\
\text { sumberdaya }\end{array}$ & \multirow{3}{*}{$\begin{array}{l}\text { - Pengelolaan } \\
\text { personalia lebih } \\
\text { menekankan } \\
\text { kelancaran } \\
\text { fungsi } \\
\text { pembelajaran } \\
\text { - Terdapat } \\
\text { formalitas dalam } \\
\text { melaksanakan } \\
\text { fungsi-fungsi } \\
\text { organisasi } \\
\text { - Pola } \\
\text { pengelolaan } \\
\text { personalia } \\
\text { belum dilakukan } \\
\text { secara } \\
\text { sistematis dan } \\
\text { terarah }\end{array}$} \\
\hline $\begin{array}{l}\infty \\
\$ \\
0 \\
0 \\
0\end{array}$ & $\begin{array}{l}\text { - Pendidik direkrut langsung, } \\
\text { pendekatan informal melalui: } \\
\text { seleksi mandiri, kerja sama } \\
\text { dengan individu/lembaga } \\
\text { - Pertimbangan: kompetensi dan } \\
\text { motivasi } \\
\text { - Pelaksanaan pengelolaan } \\
\text { berasaskan kebersamaan, bukan } \\
\text { keahlian } \\
\text { - Sistem imbalan tidak terstruktur, } \\
\text { lebih pada dukungan moral }\end{array}$ & $\begin{array}{l}\text { - Seleksi } \\
\text { proporsional; } \\
\text { - Deskripsi tugas } \\
\text { terstruktur; } \\
\text { - Kesesuaian } \\
\text { kompetensi } \\
\text { - Penilaian kinerja } \\
\text { - Sistem } \\
\text { penghargaan } \\
\text { - Pengembangan }\end{array}$ & \\
\hline 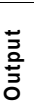 & $\begin{array}{l}\text { - Proses pembelajaran dan } \\
\text { pengelolaan sering belum dapat } \\
\text { optimal }\end{array}$ & $\begin{array}{l}\text { - Efektivitas dan } \\
\text { - Efesiensi } \\
\text { pembelajaran dan } \\
\text { pengelolaan }\end{array}$ & \\
\hline
\end{tabular}


Keempat, jalinan kemitraan kerja sama. Kerja sama merupakan suatu kegiatan yang dilakukan berdasar kesepakatan yang disetujui oleh pihak-pihak yang berkepentingan dalam rangka berbagai sumber daya seperti tenaga, material, pendanaan, dan sebagiannya untuk mencapai tujuan yang sama atau diharapkan masing-masing pihak. Kinerja PKBM pada aspek penjalinan kemitraan dideskripsikan dalam tabel 5 di bawah. Berdasarkan pemikiran evaluatif, diketahui bahwa minim kerja sama yang dilakukan PKBM khususnya dengan mitra di luar instansi Depdiknas atau aspek kerja sama horizontal adalah minim (Unesco, 2007:19-21). Penyelenggara belum memahami keberadaan dan pentingnya berbagai pihak yang ada di luar PKBM yang potensial untuk dijadikan sebagai mitra dalam pengembangan masyarakat. Hal ini dapat terjadi karena pemahaman yang keliru terhadap fungsi PKBM sendiri, ketiadaan kemampuan melakukan kerja sama dan kurang kreativitas pengelola PKBM dalam menyusun program pendidikan yang inovatif dan memiliki daya jual besar.

Tabel 5. Jalinan Kemitraan

\begin{tabular}{|c|c|c|c|}
\hline & Kenyataan & Standar & Judgment \\
\hline 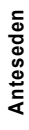 & $\begin{array}{l}\text { - Kelancaran pembelajaran dan } \\
\text { penyelenggaraan program } \\
\text { pendidikan dalam rangka } \\
\text { pengembangan masyarakat }\end{array}$ & $\begin{array}{l}\text { - Aksesibilitas } \\
\text { terhadap mitra }\end{array}$ & \multirow{3}{*}{$\begin{array}{l}\text { - Kerja sama } \\
\text { dilakukan } \\
\text { mengacu pada } \\
\text { keterlaksanaan } \\
\text { program, } \\
\text { - Belum mengacu } \\
\text { pada } \\
\text { pelaksanaan } \\
\text { fungsi kemitraan } \\
\text { dalam jangka } \\
\text { panjang dan } \\
\text { keberagaman } \\
\text { bidang kerja } \\
\text { sama sehingga } \\
\text { - Hasil yang } \\
\text { diperoleh kurang } \\
\text { optimal nampak } \\
\text { dari kerja sama } \\
\text { horizontal antar } \\
\text { lembaga masih } \\
\text { minim }\end{array}$} \\
\hline & $\begin{array}{l}\text { - Prosedur: } \\
\text { 1. Usulan ke instansi Depdiknas } \\
\text { 2.Bermitra dengan LPK pada } \\
\text { program life skills, dokumen } \\
\text { kesepakatan } \\
\text { 3. Koodinasi rutin: dinas } \\
\text { pendidikan, pemdes/tokoh masy, } \\
\text { relatif minim dengan kader } \\
\text { posyandu } \\
\text { 4.Insidental: PT, dinas sosial, } \\
\text { BLK, LSM secara informal pada } \\
\text { sedikit PKBM } \\
\text { 5. Forum antar PKBM belum } \\
\text { optimal berfungsi } \\
\text { - Berorientasi jangka pendek } \\
\text { - Minim variasi program kemitraan }\end{array}$ & $\begin{array}{l}\text { - Prosedur } \\
\text { terprogram: tujuan, } \\
\text { bidang kerja sama, } \\
\text { pendekatan, } \\
\text { pembagian } \\
\text { wewenang, waktu, } \\
\text { dsb. } \\
\text { - Kelayakan } \\
\text { - Kejelasan } \\
\text { kesepakatan } \\
\text { - Berkelanjutan } \\
\text { - Keberagaman } \\
\text { mitra dalam } \\
\text { berbagai kegiatan }\end{array}$ & \\
\hline 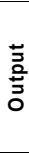 & $\begin{array}{l}\text { - Lebih pada kelancaran program } \\
\text { life skills } \\
\text { - Diperoleh fasilitas, pengalaman, } \\
\text { pendampingan } \\
\text { - Terlaksana program namun tidak } \\
\text { berkelanjutan }\end{array}$ & $\begin{array}{l}\text { - Hasil: peningkatan } \\
\text { efektivitas, } \\
\text { akuntabilitas dan } \\
\text { citra program dan } \\
\text { lembaga }\end{array}$ & \\
\hline
\end{tabular}

Kelima, monitoring dan evaluasi. Kegiatan monitoring dilakukan untuk menggambarkan bagaimana PKBM melaksanakan program atau fungsi PKBM yang direncanakan, sedangkan evaluasi dimaksudkan untuk mengetahui ketercapaian hasil dari penyelenggaraan program atau fungsi PKBM. Kegiatan monitoring dan evaluasi bukan kegiatan yang dilakukan dengan kebiasaan atau cara-cara biasa yang spontan tanpa dilakukan dengan perencanaan yang tepat. Tabel 6 menggambarkan pencapaian kinerja kelembagaan PKBM dalam melaksanakan fungsi monitoring dan evaluasi, dimana pada fungsi tersebut perlu dilakukan peningkatan kemampuan evaluatif yang dimiliki oleh personalia PKBM.
Tabel 6. Monitoring dan Evaluasi

\begin{tabular}{|c|c|c|c|}
\hline & Kenyataan & Standar & Judgment \\
\hline 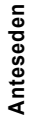 & $\begin{array}{l}\text { - Pelaksanaan program } \\
\text { pendidikan }\end{array}$ & $\begin{array}{l}\text { - Kejelasan fungsi dan } \\
\text { tujuan monitoring dan } \\
\text { evaluasi }\end{array}$ & \multirow{3}{*}{$\begin{array}{l}\text { - Belum menyentuh } \\
\text { proses evaluasi } \\
\text { yang terencana } \\
\text { pada semua } \\
\text { kegiatan atau } \\
\text { fungsi PKBM } \\
\text { - Bahan pengambilan } \\
\text { keputusan tidak } \\
\text { relevan dan } \\
\text { lengkap } \\
\text { - Perlu } \\
\text { pengembangan } \\
\text { kemampuan dan } \\
\text { instrumen evaluasi }\end{array}$} \\
\hline $\begin{array}{l}0 \\
\vdots \\
0 \\
0 \\
0\end{array}$ & $\begin{array}{l}\text { - Monev oleh pihak } \\
\text { internal dan eksternal } \\
\text { - Monitoring: 1) } \\
\text { pembelajaran dan } \\
\text { manajerial; 2) observasi } \\
\text { langsung; } \\
\text { 3) tanpa perencanaan } \\
\text { dan instrumen; 4) } \\
\text { pendekatan personal } \\
\text { - Evaluasi: Fokus proses } \\
\text { dan hasil belajar; Test }\end{array}$ & $\begin{array}{l}\text { - Kejelasan tujuan } \\
\text { - Mekanisme jelas: } \\
\text { aspek evaluasi, } \\
\text { instrumen, metode, } \\
\text { teknis analisis, } \\
\text { sumberdaya, dan } \\
\text { waktu. } \\
\text { - Objektivitas } \\
\text { - Integratif/menyeluruh } \\
\text { - Partisipasi pihak-pihak } \\
\text { tertentu } \\
\text { - Umpan balik }\end{array}$ & \\
\hline 蒿 & $\begin{array}{l}\text { - Informasi tentang hasil } \\
\text { belajar } \\
\text { - Hasil belum mencakup } \\
\text { secara utuh }\end{array}$ & $\begin{array}{l}\text { - Manfaat: masukan } \\
\text { pengambilan } \\
\text { keputusan }\end{array}$ & \\
\hline
\end{tabular}

Keenam, kegiatan dokumentasi dan disseminasi (dodis). Pendokumentasian merupakan kegiatan yang bermanfaat yaitu sebagai bahan untuk membuat rencana dan keputusan di waktu yang akan datang, dan sebagai bahan masukan untuk penentuan suatu standar minimum. Sedangkan untuk kegiatan disseminasi dimaksudkan untuk mempromosikan kegiatan-kegiatan PKBM, membantu meningkatkan dukungan dan partisipasi bagi program-program PKBM, dan membantu pencapaian bantuan teknis dan keuangan dari orang-orang yang memiliki sumber daya dan keahlian.

Tabel 7. Kegiatan Dokumentasi dan Disseminasi

\begin{tabular}{|c|c|c|c|}
\hline & Kenyataan & Standar & Judgment \\
\hline 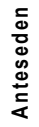 & $\begin{array}{l}\text { - Berbagai kegiatan program } \\
\text { pendidikan } \\
\text { - Menarik peserta }\end{array}$ & $\begin{array}{l}\text { - Kejelasan tujuan dan } \\
\text { fungsi dodis }\end{array}$ & \multirow{3}{*}{$\begin{array}{l}\text { - Pelaksanana } \\
\text { dodis dilakukan } \\
\text { sebatas pada } \\
\text { kegiatan } \\
\text { pendukung } \\
\text { pelaksanaan } \\
\text { program, } \\
\text { - Belum } \\
\text { mendasarkan } \\
\text { pada keberadaan } \\
\text { fungsi dodis } \\
\text { sendiri } \\
\text { - Hasil masih } \\
\text { minim dirasakan. }\end{array}$} \\
\hline $\begin{array}{l}0 \\
0 \\
0 \\
0 \\
0 \\
0\end{array}$ & $\begin{array}{l}\text { - Mekanisme dokumentasi } \\
\text { dan disseminasi relatif } \\
\text { sederhana dan murah } \\
\text { - Dokumentasi dengan foto } \\
\text { dan laporan } \\
\text { - Disseminasi melalui: peran } \\
\text { tokoh setempat, aktivitas } \\
\text { social, gethok tular; Sedikit } \\
\text { dengan cara: pameran, } \\
\text { leaflet, radio lokal. }\end{array}$ & $\begin{array}{l}\text { - Mekanisme } \\
\text { terencana: } \\
\text { tujuan/sasaran, } \\
\text { aspek, pelaksana, } \\
\text { cara, waktu, dan } \\
\text { manfaat. } \\
\text { - Kelayakan } \\
\text { - Variasi kegiatan/cara }\end{array}$ & \\
\hline 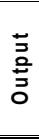 & $\begin{array}{l}\text { - Sebatas pengadministrasian } \\
\text { - Tersampaikan informasi } \\
\text { tentang PKBM kepada } \\
\text { masyarakat dan kelompok } \\
\text { sasaran } \\
\end{array}$ & $\begin{array}{l}\text { - Pengelolaan } \\
\text { pengetahuan } \\
\text { - Peningkatan } \\
\text { partisipasi } \\
\text { masyarakat } \\
\end{array}$ & \\
\hline
\end{tabular}

Tabel di atas memberikan gambaran bahwa pelaksanaan fungsi pendokumentasian dan disseminasi yang dilakukan PKBM belum dilaksanakan secara terencana, belum menggunakan cara-cara yang bervariatif dan inovatif yang mendukung pada pencapaian tujuan PKBM. Oleh karena itu, kemampuan PKBM dalam aspek ini perlu dikembangkan misalnya meningkatkan kemampuan pengelolaan dokumen yang tertib dan bermanfaat, kemampuan pengembangan media-media informasi, dan kemampuan mengelola berbagai kegiatan yang ditujukan pada khalayak luas. 
Ketujuh, pengembangan kapasitas personalia. Pengembangan kapasitas dimaknai sebagai upaya untuk meningkatkan kemampuan fungsi dan peran individu maupun organisasi dalam mencapai tujuan lembaga. Terkait dengan ini, pengembangan kapasitas personalia yang dilakukan PKBM disajikan dalam tabel 8 berikut:

Tabel 8. Pengembangan kapasitas personalia

\begin{tabular}{|c|c|c|c|}
\hline & Kenyataan & Standar & Judgement \\
\hline 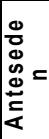 & $\begin{array}{l}\text { - Program pengembangan } \\
\text { organisasi lain }\end{array}$ & $\begin{array}{l}\text { - Kejelasan dan } \\
\text { penentuan kebutuhan } \\
\text { pengembangan } \\
\text { individu dan organisasi }\end{array}$ & \multirow{3}{*}{$\begin{array}{l}\text { - Pengembang } \\
\text { an SDM } \\
\text { secara } \\
\text { mandiri dan } \\
\text { terprogram } \\
\text { belum dapat } \\
\text { diwujudkan } \\
\text { sehingga } \\
\text { manfaat } \\
\text { optimal } \\
\text { belum } \\
\text { tercapai }\end{array}$} \\
\hline $\begin{array}{l}0 \\
0 \\
0 \\
0 \\
2 \\
0\end{array}$ & $\begin{array}{l}\text { - Pengiriman tendik ke } \\
\text { lembaga diklat minimal } \\
\text { setiap tahun sekali } \\
\text { - Sedikit PKBM memiliki } \\
\text { fasilitas internet } \\
\text { - Diskusi sejawat } \\
\text { - Belajar mandiri }\end{array}$ & $\begin{array}{l}\text { - Terprogram: } \\
\text { 1) Desain, } \\
\text { 2) Pelaksanaan, } \\
\text { 3) Evaluasi } \\
\text { - Variatif kegiatan } \\
\text { - Dukungan } \\
\text { sumberdaya } \\
\text { - Kontinuitas } \\
\end{array}$ & \\
\hline$\frac{\pi}{3}$ & $\begin{array}{l}\text { - Pemahaman tutor meningkat } \\
\text { - Dampak lanjutan pada } \\
\text { lembaga belum optimal }\end{array}$ & $\begin{array}{r}\text { - Peningkatan } \\
\text { produktivitas }\end{array}$ & \\
\hline
\end{tabular}

Dari tabel di atas diketahui cara pengembangan personalia yang dilakukan PKBM yang diteliti belum memiliki kerangka kerja untuk pengembangan sumber daya manusia yang terencana atau terprogram dalam rangka pengembangan kelembagaan PKBM. PKBM masih mengandalkan kesempatan-kesempatan yang disediakan oleh pihak luar. Hal ini menyebabkan fungsi PKBM tidak dapat berjalan dengan baik dalam jangka panjang, mengingat personalia yang dimiliki PKBM mengalami masalah dalam hal peregenerasian.

Kedelapan, dalam konteks pengembangan masyarakat, nampaknya PKBM yang diteliti masih belum mampu menjadikan dirinya menjadi lembaga pendidikan yang efektif (Cheng, YH., 1996:18) yaitu lembaga pendidikan yang menjadikan sasarannya dapat berdaya pada level individu, kelas, institusi, maupun konteks masyarakat lokal, nasional dan internasional. Hasil penelitian menunjukkan bahwa PKBM baru memberikan layanan minimal kepada warga masyarakat atau kelompok sasaran untuk memiliki berbagai kemampuan dasar yang diorientasikan pada pemenuhan kebutuhan pendidikan minimal dan kemampuan untuk membuka lapangan usaha atau bekerja dengan orang lain. Namun, dampak dari pelaksanaan berbagai kegiatan atau aktivitas pendidikan yang dilakukan PKBM terhadap kehidupan masyarakat belum dapat optimal. Perubahan sosial masyarakat ke arah kemajuan, peningkatan partisipasi politik masyarakat, penurunan tingkat kemiskinan, dan peningkatan mobilitas sosial belum dapat terjadi secara menyeluruh dan optimal.

Kesembilan, terdapat berbagai kendala yang dihadapi oleh PKBM dalam melaksanakan perannya untuk mencapai tujuan lembaga. Dari hasil penelitian, diperoleh informasi mengenai berbagai kendala yang dihadapi PKBM yang mempengaruhi pencapaian tujuan pendidikan sebagai mana dalam Tabel 9.

Tabel 9. Kendala-kendala pengelolaan

\begin{tabular}{|c|c|c|c|c|}
\hline \multirow{2}{*}{\multicolumn{2}{|c|}{ PKBM }} & \multicolumn{3}{|c|}{ Aspek } \\
\hline & & Struktur & Interaksi & Kultur \\
\hline \multirow[b]{2}{*}{ 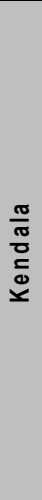 } & $\begin{array}{l}\bar{\pi} \\
\stackrel{5}{ \pm} \\
\stackrel{ \pm}{\Xi}\end{array}$ & $\begin{array}{l}\text { - Jabatan rangkap } \\
\text { pengelola/ } \\
\text { penyelenggara } \\
\text { - Formalitas } \\
\text { - Regenerasi } \\
\text { pengelola minim } \\
\end{array}$ & $\begin{array}{l}\text { - Kesibukan warga } \\
\text { belajar } \\
\text { - Peran ganda } \\
\text { personalia/tutor } \\
\text { - Personalia Kurang } \\
\text { professional } \\
\end{array}$ & $\begin{array}{l}\text { - Takut mencoba } \\
\text { - Budaya } \\
\text { menunggu } \\
\text { - Ketergantung-an }\end{array}$ \\
\hline & 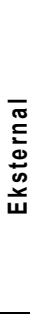 & $\begin{array}{l}\text { - Ego sektoral } \\
\text { - Dukungan pemdes } \\
\text { kurang } \\
\text { - Minim lembaga- } \\
\text { lembaga sosial } \\
\text { seperti LSM, dll } \\
\text { - Letak geografis } \\
\text { kurang mendukung } \\
\text { - Birokrasi pemerintah } \\
\text { yang menghambat }\end{array}$ & $\begin{array}{l}\text { - } \text { Perijinan dari } \\
\text { pemdes } \\
\text { menghambat } \\
\text { - Sarana sosialisasi } \\
\text { ke pihak luar } \\
\text { kurang } \\
\text { - Fungsi } \\
\text { komite/forum } \\
\text { belum optimal } \\
\text { - Keamanan kurang }\end{array}$ & $\begin{array}{l}\text { - Kesadaran } \\
\text { masyarakat } \\
\text { minim } \\
\text { - Adat istiadat } \\
\text { masyarakat }\end{array}$ \\
\hline
\end{tabular}

Kendala-kendala yang dialami PKBM telah berpengaruh pada pelaksanaan fungsi-fungsi PKBM misalnya proses pembelajaran sering terganggu akibat kehadiran warga belajar yang lebih memilih bekerja pada saat waktu pembelajaran yang telah ditentukan, belum adanya dukungan pendanaan dari pemerintah desa, kurangnya dukungan fasilitas dari instansi nonDepdiknas, dan kedudukan PKBM di masyarakat luas yang masih sebagai lembaga pendidikan alternatif.

Berdasarkan hasil penelitian dan pemikiranpemikiran sebagaimana dikemukakan di atas, penting untuk segera melakukan tindakan yang diorientasikan untuk mengembangkan efektivitas lembaga PKBM. Peningkatan dilakukan dalam segala proses atau peningkatan jaminan mutu pada lembaga PKBM (Bush \& Coleman, 2006:151-189). Berbagai upaya pengembangan dapat dimulai dengan meninjau kembali keadaan lembaga PKBM pada saat sekarang, memahami berbagai kebutuhan-kebutuhan pengembangan, mencari berbagai alternatif upaya pengembangan, melaksanakan berbagai upaya pengembangan, dan menentukan penilaian terhadap upaya pengembangan yang dilakukan. Tentunya, pengembangan yang dilakukan PKBM membutuhkan dukungan dan komitmen dari semua pihak baik langsung terlibat maupun tidak terhadap keberadaan dan manfaat PKBM. 


\section{KESIMPULAN}

\section{Kesimpulan}

Ditinjau dari pemikiran evaluatif terhadap aspek anteseden, proses, dan output setiap fungsi kelembagaan PKBM yang mencakup pengidentifikasian kebutuhan, perencanaan dan pengorganisasian program pendidikan, mobilisasi dan pemanfaatan sumber daya, pembinaan kemitraan dan jaringan, monitoring dan evaluasi, pelaksanaan dokumentasi dan disseminasi, dan pengembangan kapasitas personalia diketahui bahwa setiap fungsi belum mampu terlaksana secara optimal dalam mencapai hasil atau keadaan optimal yang sesuai dengan harapan. Kekurang-optimalan pelaksanaan setiap fungsi kelembagaan mempengaruhi pencapaian tujuan PKBM sebagai pengembang masyarakat di mana perubahan perilaku kelompok sasaran atau warga masyarakat belum berdampak pada perubahan-perubahan sosial yang lebih kompleks dan belum berimbas kepada kepada kehidupan masyarakat secara keseluruhan. Selain itu, kendala yang ada juga mempengaruhi keberhasilan pencapaian tujuan PKBM di mana PKBM dihadapkan pada kendala yang berasal dari eksternal maupun internal lembaga yang bersifat struktural, interaksional, dan kultural. Kendala-kendala ini telah menyebabkan berbagai dampak negatif terhadap pengelolaan program, proses pembelajaran, pemanfaatan hasil belajar, pengemba- ngan partisipasi masyakat, perilaku personalia, dan sebagainya.

\section{Saran}

Saran-saran yang dapat disampaikan berdasarkan pada hasil kesimpulan di atas sebagai berikut a) penyelenggara/personalia PKBM perlu berperilaku profesional dan dengan pemahaman utuh dalam menjalankan tugas dan fungsinya disertai dengan selalu mengembangkan perilaku gemar belajar, b) penyelenggara/pengelola PKBM perlu terus mengembangkan jaringan kerja sama yang bersifat saling menguntungan dan berkelanjutan. Penyelesaian / pengelolaan PKBM selalu berpikir positif dan berperilaku kontruktif pada berbagai kendala yang dihadapi dalam membina kemitraan dengan pihak lain, c) tutor perlu terus meningkatkan pemahaman mengenai pembelajaran pada pendidikan nonformal dan menyediakan kelengkapan pembelajaran yang dilandasi kaidah-kaidah pendidikan guna penjaminan mutu pembelajaran, dan d) para pihak berkepentingan baik perseorangan, kelompok, ataupun instansi pemerintah dan/atau swasta perlu mengubah pemikiran yang tersegment terhadap fungsi PKBM sehingga pengembangan masyarakat dapat dilakukan secara terintegrasi.

\section{DAFTAR PUSTAKA}

Bush, T. \& Coleman, M. (2006). Manajemen strategis: Kepemimpinan pendidikan. Terjemahan Farrorozi. Yogyakarta : IRCiSoD.

Cheng, Y.C. (1996). School effectiveness and school based management: A mechanism for development. London: Palmer Press.

Galbraith, M.W. (1995). Community-based organization and the delivery of lifelong learning opportunities. Washington: U.S. Department of Education.

Ife, J. (1997). Community development: Creating community alternatives-vision, analysis, and practice. Melbourne: Longman.

Korten, D.C. (1986). Community management: Asian experience and perspectives. West Hartford C.: Kumarian Press.

Miles, M.B. \& Huberman, A. M. (2007). Analisis data kualitatif. Terjemahan Tjetjep Rohendi Rohindi. Jakarta: Penerbit Universitas Indonesia.
Stuffleebeam, D. L., \& Shinkfield, A. L. (1984). Systematic evaluation: A self instructional guide to theory and practice. Boston: Kluwer-Nijhoff Publishing.

Unesco. (2007). Strengthening community learning centre through linkages and networks: $A$ synthesis of six country reports. Bangkok: Unesco Asia and Pasific Regional Bureau for Education.

Unesco. (2008). CLC management handbook. Diakses pada tanggal 12 Agustus 2008 dari www.unesdoc.unesco.org.

Zaenudin, A. (2003). Pengelolaan dan pemberdayaan pusat kegiatan belajar masyarakat. Makalah disampaikan pada Rapat Koordinasi Penyelenggaraan Backstopping PKBM, tanggal 5-6 November 2003 di Solo. 